\title{
Ekstensi TAM untuk Memprediksi Niat Menggunakan E-Money di Pontianak
}

\author{
Explaining Intention to Use E-Money in Pontianak \\ an Extended TAM Study
}

\author{
Irawan Wingdes \\ STMIK Pontianak \\ E-mail: emirawan.wingdes@gmail.com
}

\begin{abstract}
Abstrak
E-money berbasis smart card diwajibkan pemerintah daerah sejak tahun 2018 untuk pengisian bahan bakar tetapi publikasi data sekunder menunjukkan hasil tidak sesuai harapan. Penelitian kuantitatif ini bertujuan untuk memprediksi niat menggunakan e-money dengan mengekstensikan rational choice theory dengan faktor benefit of compliance, cost of compliance, cost of non compliance dan perceived speed pada technology acceptance model. Data dikumpulkan dengan survei menggunakan kuesioner, data diolah dan hipotesis diuji dengan structural equation modeling berbasis partial least square. Jumlah sampel dengan purposive method yang dikumpulkan adalah 336 responden (slovin) dengan margin of error 5\% untuk populasi pengguna kendaraan di Pontianak. Pengujian menunjukkan faktor yang digunakan valid dan reliabel, dengan hasil: transaction speed, perceived ease of use, perceived usefulness, benefit of compliance, cost of compliance, cost of non compliance mempengaruhi behavioral intention. Faktor yang mempengaruhi paling kuat niat menggunakan adalah cost of non compliance dan perceived transaction speed. Hasil menunjukkan pengguna akan berniat menggunakan e-money bila diwajibkan dan disertai dengan sanksi
\end{abstract}

Kata kunci-E-money, Ekstensi TAM, Rational Choice Theory, Behavioral Intention

\begin{abstract}
Smart card based e-money was required by local authorities since 2018 for refueling activity in Pontianak but results were not as expected. Therefore, this quantitative study aims to predict intention to use e-money by extending rational choice theory with its antecedents: benefit of compliance, cost of noncompliance, cost of compliance and perceived transaction speed to technology acceptance model. Data for analysis was acquired using questionaire based survey. Hypotheses are tested by utilizing partial least square based structural equation modeling. A total of 336 samples (slovin) from total vehicles owners in Pontianak are acquired using purposive method with margin of error of 5\%. Test results shows antecedents extended to TAM are valid and reliable with transaction speed, perceived ease of use, perceived usefulness, benefit of compliance, cost of compliance, cost of non compliance significantly influences intention to use. Factors with greatest influence are cost of non compliance and transaction speed. Results suggest user's intention to use e-money in mandatory situation are influenced strongly only when there are consequences imposed at non compliance.
\end{abstract}

Key words_E-money, extended TAM, Rational Choice Theory,Behavioral Intention 


\section{PENDAHULUAN}

Gerakan Nasional Non Tunai (GNNT) dimulai oleh bank Indonesia sejak tahun 2014. Gerakan tersebut ditujukan untuk meningkatkan kesadaran masyarakat terhadap penggunaan instrumen non tunai. GNNT diselenggarakan setiap tahun dan diharapkan dapat membentuk suatu komunitas atau masyarakat yang lebih memilih menggunakan instrumen pembayaran non tunai (less cash society/LCS) [1]. Instrumen non tunai tersebut kemudian dikenal dengan sebutan emoney.

E-money pada hakikatnya adalah sebagai pengganti uang tunai, penerbitannya atas dasar nilai uang yang disetor yang saldonya tersimpan pada suatu media. E-money dapat dikategorikan berdasarkan lingkup penyelenggaraannya (closed loop dan open loop), berdasarkan media penyimpan nilai uang elektronik (server based dan chip based), dan berdasarkan pencatatan data identitas pengguna (unregistered dan registered). [2][3]

Di Pontianak, pencanangan untuk mendukung gerakan nasional non tunai sudah disosialisasikan pada stasiun pengisian bahan bakar sejak tahun 2017 untuk pelaksanaan tahun 2018 [4]. Pada peraturan daerah tersebut, stasiun pengisian bahan bakar di Pontianak kota wajib menggunakan e-money pada proses pengisian bahan bakar. Walaupun sudah diwajibkan, pada implementasinya, masih terdapat kendala sehingga hasil tidak sesuai yang diharapkan. Beberapa diantaranya dapat dilihat dari data sekunder dalam bentuk publikasi untuk wilayah Pontianak, yaitu 1. Stasiun pengisian bahan bakar menerapkan wajib menggunakan e-money hanya pada antrian produk bahan bakar premium (penerapan tidak menyeluruh) [5], 2. Masyarakat tidak antusias dengan kartu e-money yang ditandai dengan penjualan kartu yang rendah [6], 3. Masyarakat tidak berniat menggunakan e-money untuk pengisian bahan bakar [7].

E-money yang diwajibkan untuk digunakan di Pontianak merupakan e-money berbasis kartu atau smart card seperti kartu Flazz, Brizzi, atau Mandiri E-money dan sejenisnya. Smart card adalah teknologi yang digunakan untuk menyimpan data secara elektronis yang kemudian dapat digunakan untuk berbagai kebutuhan termasuk untuk transaksi. Pada smart card berbasis contactless seperti RFID dan NFC, selain tidak memerlukan kontak langsung, saat pada pemrosesan sangat cepat [8] [9].

Niat menggunakan e-money merupakan faktor penting dalam menentukan penggunaan e-money. Penelitian-penelitian sebelumnya yang membahas tentang niat menggunakan e-money di Indonesia yaitu di daerah Yogyakarta dengan kerangka theory of planned behavior (TPB) [10] mendapatkan hasil bahwa niat menggunakan e-money lebih dipengaruhi oleh faktor internal seperti pandangan internal terhadap e-money (attitude) dan kepercayaan diri (perceived behavioral control) daripada faktor eksternal seperti tekanan sosial (subjective norms). Sedangkan pada studi serupa di daerah Jakarta, yang juga dengan menggunakan kerangka TPB, niat menggunakan e-money berbasis server dipengaruhi oleh kepercayaan diri dan tekanan sosial tetapi tidak dipengaruhi oleh pandangan internal akan e-money [11].

Studi terdahulu tidak membahas niat menggunakan e-money pada situasi diwajibkan oleh pemerintah dan e-money yang diteliti bukan berbasis kartu seperti yang diwajibkan di Pontianak. Untuk itu penelitian ini bertujuan untuk menyelidiki niat menggunakan e-money di Pontianak dan mengisi gap penelitian terdahulu tersebut dengan menggunakan teori technology acceptance model (TAM) yang diekstensikan dengan rational choice theory (RCT) dan perceived transaction speed (TS). Secara teoritis, penelitian ini akan berkontribusi pada ekstensi rational choice theory dan perceived transaction speed pada technology acceptance model dalam konteks e-money berbasis smart card.

Technology acceptance model (TAM) digunakan karena parsimoni dan teruji untuk penerimaan teknologi ataupun sistem baru [12] [13] [14]. Pada TAM, persepsi manfaat dan kemudahan penggunaan mempengaruhi niat menggunakan yang akhirnya mempengaruhi penggunaan. TAM mempunyai kelebihan lain yaitu dapat di ekstensikan dengan teori lain untuk menjelaskan niat menggunakan [13]. Dengan mempertimbangkan e-money sudah diwajibkan pemerintah tetapi belum diterima / masih dilanggar dan terdapat kendala kecepatan transaksi, ekstensi yang digunakan pada penelitian ini bertujuan untuk mengkaji lebih jauh mengapa 
pengguna belum mematuhi aturan wajib e-money sehingga terjadi kendala implementasi. Kedua, bagaimana persepsi pengguna pada kecepatan transaksi e-money, mengapa masih terdapat kendala karena secara teknologi, proses transaksi e-money seharusnya tidak lambat.

Rational Choice Theory (RCT) diutilisasi untuk mengkaji kepatuhan terhadap peraturan pada pengguna. Kepatuhan akan peraturan secara rasional terdiri dari tiga faktor, yaitu benefit of compliance (keuntungan mematuhi aturan), cost of compliance (kerugian mematuhi aturan) dan cost of non compliance (kerugian tidak mematuhi aturan) [15] [16], ketiga faktor dari RCT ini diekstensikan pada TAM untuk mengkaji pengaruhnya terhadap niat menggunakan e-money dan diharapkan dapat memberikan pemahaman lebih mendalam akan kepatuhan pengguna pada program wajib e-money di Pontianak.

Sedangkan untuk kecepatan transaksi, faktor perceived transaction speed diutilisasi untuk mengkaji pengaruhnya terhadap niat menggunakan e-money. Pada penelitian sebelumnya, persepsi transaksi yang cepat akan memberikan rasa kendali yang tinggi bagi pengguna dan mempengaruhi niat menggunakan secara langsung maupun secara tidak langsung melalui persepsi manfaat [17] [18]. Dari kedua ekstensi ini, diharapkan didapatkan pemahaman maupun solusi baru terhadap kendala yang terjadi pada program wajib e-money di Pontianak dari sisi pengguna.

\section{METODE PENELITIAN}

Metode penelitian yang digunakan untuk mencapai tujuan penelitian adalah eksplanatori kuantitatif [19]. Pengumpulan data dilakukan dengan survei menggunakan kuesioner. Data dikumpulkan dengan mengambil sampel pengguna kendaraan di Pontianak yang berjumlah total 1.023.464 unit [20]. Jumlah sample dihitung dengan menggunakan metode Slovin (confidence interval 95\%, margin of error 5\%) [19] dan penyebaran kuesioner dilakukan menggunakan judgement sampling pada beberapa stasiun pengisian bahan bakar di Pontianak yang dipilih secara acak. Total kuesioner yang dapat dianalisis lebih lanjut berjumlah 336 responden. Data dianalisis dengan structural equation modeling berbasis partial least square dengan bantuan software SmartPLS 3.2.8.

\subsection{Hipotesis}

\subsubsection{Technology Acceptance Model}

TAM dikembangan oleh Davis sejak tahun 1986 dimana TAM dikembangkan melalui Theory of Reasoned Action (TRA). Model TAM mengikuti TRA dimana penggunaan sistem informasi atau teknologi (behavior) akan ditentukan oleh niat menggunakan (behavioral intention / BI). BI dipengaruhi oleh perceived usefulness (PU) dan perceived ease of use (EU) dan dapat diekstensikan dengan konstruk lain untuk mendapatkan pemahaman lebih akan niat menggunakan sebuah teknologi atau sistem baru [12][13][14].

1. Perceived Usefulness (PU)

Perceived usefulness pada penelitian asli TAM merupakan persepsi subjektif dari pengguna dimana menggunakan sistem tertentu akan meningkatkan performa pekerjaan dalam organisasi. Pada penelitian lanjutan, PU digunakan untuk mengukur persepsi manfaat yang diberikan oleh sebuah teknologi ataupun sistem tertentu [12] [13] [14]. PU mempengaruhi behavioral intention secara langsung sehingga hipotesis dirumuskan sebagai berikut:

H1: Perceived usefulness mempengaruhi Behavioral Intention secara positif 
2. Perceived ease of use (EU)

Perceived ease of use atau persepsi kemudahan penggunaan dibentuk dari self efficacy dan personal control dari teori yang dikembangkan Bandura. Kemudahan (yang ditandai dengan usaha yang minimal) akan meningkatkan self efficacy (kepercayaan diri) pengguna dan personal control (kendali) sehingga akan mempengaruhi motivasi internal pengguna. Semakin mampu dan dapat dikendalikan, akan semakin bermanfaat dan berniat menggunakan $[12,13,14]$. Dengan demikian. EU akan mempengaruhi behavioral intention dan perceived usefulness secara positif dan hipotesis dirumuskan sebagai berikut:

H2a: ease of use akan mempengaruhi pu secara positif

H2b: ease of use akan mempengaruhi bi secara positif

3. Behavioral intention (BI)

BI adalah faktor utama yang mempengaruhi tindakan atau behavior. Dalam Theory of Reasoned Action yang diadaptasi pada Technology Acceptance Model, niat akan selalu mempengaruhi behavior / tindakan. Jadi seseorang akan melakukan sebuah tindakan akan selalu harus terlebih dahulu mempunyai niat untuk melakukan tindakan tersebut. faktor lain yg mempengaruhi behavior akan selalu melalui behavioral intention [12] [13] [14] [21] [22].

\subsubsection{Rational Choice Theory}

Rational Choice Theory (RCT) menjelaskan kepatuhan akan peraturan melalui pertimbangan rasional yaitu untung rugi dari mematuhi aturan. RCT berasal dari ranah kriminologi dan kemudian berkembang pada bidang sistem informasi untuk menjelaskan kepatuhan pada peraturan keamanan komputer [15]. Pertimbangan untung rugi merupakan keputusan subjektif dari pengguna, sehingga apakah sebuah peraturan akan dilanggar atau diterima, sepenuhnya bergantung kepada persepsi subjektif dari pengguna, terlepas dari apakah persepsi tersebut benar atau salah secara objektif. [16].

Penelitian ini mengambil faktor yang dikembangkan pada studi yang dilakukan Bulgurcu [15] karena penelitian tersebut membedakan dengan jelas teori RCT / pertimbangan rasional dalam mengikuti aturan menjadi 3 faktor. Tiga faktor yang digunakan pada studi tersebut juga digunakan pada penelitian ini, yaitu: Perceived Benefit of Compliance (BC) atau persepsi dari keuntungan/manfaat yang timbul karena mengikuti aturan, Perceived Cost of Compliance (CC) atau persepsi dari biaya/kerugian yang timbul karena mengikuti aturan, dan Perceived Cost of Non Compliance (CNC) atau persepsi dari biaya/kerugian yang timbul karena tidak mengikuti aturan.

Secara rasional sesuai kerangka teori RCT, seseorang akan lebih memilih tindakan yang memberikan keuntungan / manfaat bagi dirinya sehingga bila mengikuti aturan dan memberikan keuntungan, tindakan tersebut akan bernilai positif atau menambah niat. Sebaliknya yang merugikan akan tidak disukai karena terdapat biaya / kerugian yang ditimbulkan dari mengikuti aturan, dan itu akan mempengaruhi niat secara negatif atau mengurangi niat. Kemudian pada kerugian karena tidak mengikuti aturan, juga sama seperti keuntungan karena biaya dari tidak mengikuti aturan akan mengakibatkan kerugian sehingga semakin tinggi biaya dari tidak mengikuti aturan, maka niat untuk mengikuti aturan juga akan tinggi. Hipotesis yang dibentuk dengan demikian adalah:

H3a: perceived benefit of compliance mempengaruhi niat menggunakan secara positif. H3b: perceived cost of compliance mempengaruhi niat menggunakan secara negatif H3c: perceived cost of noncompliance mempengaruhi niat menggunakan secara positif 


\subsubsection{Perceived Transaction Speed}

Faktor ini dikembangkan oleh Chen [17] yang divalidasi kembali oleh Yang [18] untuk konteks pembayaran elektronik menggunakan media mobile berteknologi NFC. secara proses, pembayaran melalui NFC sama dengan contactless smart card dimana pengguna hanya perlu mendekatkan kartu ke pembaca dan transaksi sudah tercatat otomatis. Persepsi kecepatan transaksi (TS) dapat didefinisikan sebagai waktu yang dipersepsikan perlu untuk melakukan sebuah transaksi. Persepsi dapat berbeda dengan kecepatan sebenarnya yang terjadi pada transaksi. Persepsi transaksi yang cepat menambah kendali bagi pengguna sehingga persepsi kecepatan tersebut pada akhirnya akan mempengaruhi persepsi kemudahan maupun persepsi manfaat dari sebuah sistem. Oleh karena itu, TS merupakan faktor yang mempengaruhi ease of use, usefulness dan behavioral intention dan hipotesis dirumuskan sebagai berikut:

$\mathrm{H}_{4 a}$ : persepsi kecepatan transaksi mempengaruhi ease of use secara positif $\mathrm{H}_{4 b}$ : persepsi kecepatan transaksi mempengaruhi usefulness secara positif. $\mathrm{H}_{4 c}$ : persepsi kecepatan transaksi mempengaruhi bi secara positif

Model konseptual penelitian ini dapat dilihat pada Gambar 1 dan ringkasan faktor serta teori asal yang digunakan dapat dilihat pada tabel 1 .

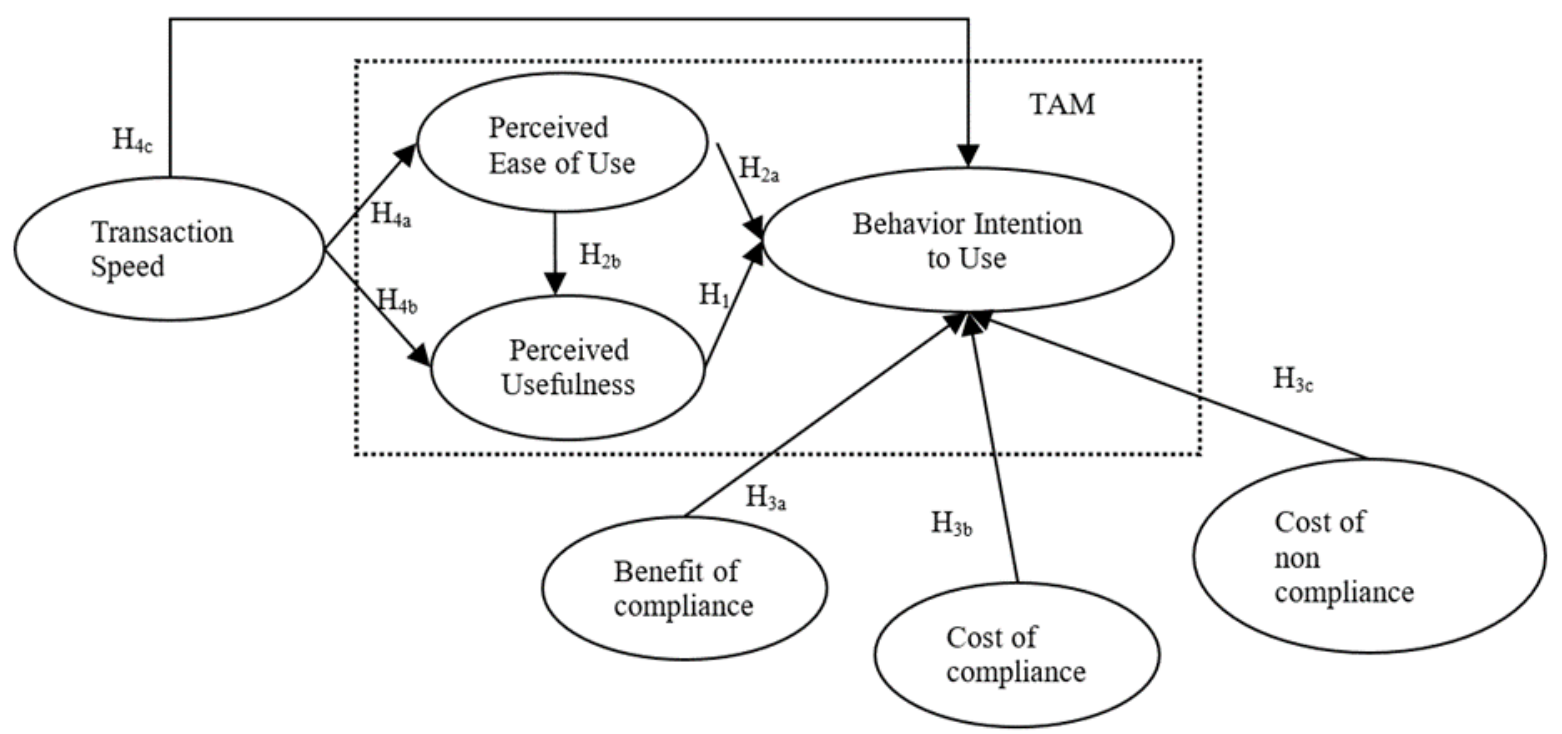

Gambar 1. Model Konseptual Penelitian

Tabel 1. Ringkasan Faktor dan Teori dasar

\begin{tabular}{|l|l|l|}
\hline Faktor & Definisi & Sumber \\
\hline Perceived & Persepsi akan manfaat dari & Technology acceptance model \\
Usefulness & menggunakan e-money & $12][13][14]$ \\
\hline $\begin{array}{l}\text { Perceived } \\
\text { Ease of Use }\end{array}$ & $\begin{array}{l}\text { Persepsi kemudahan penggunaan e- } \\
\text { money }\end{array}$ & $\begin{array}{l}\text { Technology acceptance model } \\
{[12][13][14]}\end{array}$ \\
\hline $\begin{array}{l}\text { Transaction } \\
\text { Speed }\end{array}$ & $\begin{array}{l}\text { Persepsi kecepatan proses dalam } \\
\text { transaksi menggunakan e-money. }\end{array}$ & $\begin{array}{l}\text { Extended Technology acceptance } \\
\text { model [21][22] }\end{array}$ \\
\hline $\begin{array}{l}\text { Benefit of } \\
\text { Compliance }\end{array}$ & $\begin{array}{l}\text { Persepsi akibat positif dari mengikuti } \\
\text { aturan wajib e-money }\end{array}$ & Rational Choice Theory [15][16] \\
\hline $\begin{array}{l}\text { Cost of } \\
\text { Compliance }\end{array}$ & $\begin{array}{l}\text { Persepsi akibat negatif dari mengikuti } \\
\text { aturan wajib e-money }\end{array}$ & Rational Choice Theory [15][16] \\
\hline $\begin{array}{l}\text { Cost of Non } \\
\text { Compliance }\end{array}$ & $\begin{array}{l}\text { Persepsi akibat negatif dari tidak } \\
\text { mengikuti aturan wajib e-money }\end{array}$ & Rational Choice Theory [15][16] \\
\hline
\end{tabular}


Citec Journal, Vol. 5, No. 4, Agustus 2018 - Oktober 2018

ISSN: 2460-4259

\begin{tabular}{|l|l|l|}
\hline Faktor & Definisi & Sumber \\
\hline Behavioral & Niat untuk melakukan bertransaksi & Theory of Reasoned Action, [21] \\
Intention & menggunakan e-money & Theory of Planned Behavior [22] \\
& & Technology acceptance model \\
& & $[12][13] 14]$ \\
\hline
\end{tabular}

\subsection{Alat Ukur}

Alat ukur/pertanyaan kuesioner (indikator) didefinisikan berdasarkan teori asal dan diadaptasi untuk penelitian ini. Indikator diuji terlebih dahulu dengan pretest dimana kuesioner disebarkan ke kelompok kecil untuk diuji validitas dan reliabilitasnya untuk kemudian disesuaikan kembali. Setelah dilakukan pretest dan penyesuaian, terdapat dua pertanyaan yang dinilai berulang (karena keunggulan dan keuntungan sulit dibedakan responden) sehingga dihilangkan, indikator final beserta deskripsi dapat dilihat pada Tabel 2. Alat ukur menggunakan skala likert 1 (negatif / sama sekali tidak setuju) - 8 (positif / sangat setuju sekali) tanpa nilai tengah.

Nilai mean dan standar deviasi serta nilai validitas hasil pengujian disajikan pada Tabel 2. Selain itu, jumlah respons pengguna juga dibagi menjadi yang positif (nilai 5-8) dan negatif (nilai 1-4) dalam persentase.

Tabel 2. Alat ukur, Mean, Standar Deviasi, Loading Factor dan konsolidasi skor

\begin{tabular}{|c|c|c|c|c|c|c|}
\hline & Pertanyaan & Mean & StD & $\begin{array}{l}\text { Load- } \\
\text { ing }\end{array}$ & $\begin{array}{l}\text { Skor } \\
1-4 *\end{array}$ & $\begin{array}{l}\text { Skor } \\
5-8 *\end{array}$ \\
\hline PU1 & $\begin{array}{l}\text { Menggunakan E-money membuat transaksi saya } \\
\text { lebih efisien }\end{array}$ & 3,85 & 0,97 & 0,874 & 75,60 & 24,40 \\
\hline PU2 & $\begin{array}{l}\text { Menggunakan E-money membuat transaksi saya } \\
\text { lebih efektif }\end{array}$ & 3,65 & 0,99 & 0,821 & 72,32 & 16,96 \\
\hline PU3 & $\begin{array}{l}\text { Saya merasa menggunakan E-money itu berguna / } \\
\text { bermanfaat }\end{array}$ & 3,60 & 0,98 & 0,842 & 82,44 & 17,56 \\
\hline EU1 & E-money mudah dipelajari penggunaannya & 4,35 & 0,98 & 0,843 & 59,82 & 40,17 \\
\hline EU2 & E-money itu sederhana / tidak kompleks & 4,27 & 1,01 & 0,846 & 59,22 & 40,77 \\
\hline EU3 & E-money mudah digunakan pada saat transaksi & 3,88 & 1,05 & 0,851 & 71,72 & 28,27 \\
\hline BI1 & Saya berniat menggunakan e-money di masa depan & 6,63 & 0,97 & 0,867 & 1,19 & 98,80 \\
\hline BI2 & $\begin{array}{l}\text { Saya berniat menggunakan e-money sedapat } \\
\text { mungkin }\end{array}$ & 4,84 & 1,03 & 0,849 & 36,90 & 63,09 \\
\hline BI3 & $\begin{array}{l}\text { Saya berniat untuk merekomendasikan e-money } \\
\text { kepada orang lain }\end{array}$ & 5,63 & 1,07 & 0,841 & 14,58 & 85,41 \\
\hline TS1 & $\begin{array}{l}\text { Saya percaya menggunakan e-money akan } \\
\text { meningkatkan kecepatan transaksi saya }\end{array}$ & 4,52 & 1,25 & 0,843 & 50,60 & 49,40 \\
\hline TS2 & $\begin{array}{l}\text { Saya percaya menggunakan e-money akan } \\
\text { menghemat waktu saya }\end{array}$ & 4,57 & 1,26 & 0,846 & 55,36 & 44,64 \\
\hline \multirow[t]{2}{*}{ TS3 } & $\begin{array}{l}\text { Dibandingkan dengan pembayaran menggunakan } \\
\text { uang tunai, saya percaya membayar dengan e-money } \\
\text { juga prosesnya cepat }\end{array}$ & 4,92 & 1,11 & 0,851 & 34,82 & 65,18 \\
\hline & $\begin{array}{l}\text { Dengan mengikuti aturan wajib menggunakan e- } \\
\text { money di pengisian bahan bakar, }\end{array}$ & & & & & \\
\hline BC1 & $\begin{array}{l}\text { Akan diutamakan bagi saya (berusaha mengikuti } \\
\text { aturan) }\end{array}$ & 4,31 & 1,04 & 0,845 & 57,14 & 42,85 \\
\hline BC2 & Memberikan faedah bagi saya & 4,73 & 1,09 & 0,874 & 41,07 & 58,92 \\
\hline \multirow[t]{2}{*}{ BC3 } & Menguntungkan bagi saya & 4,54 & 1,03 & 0,866 & 48,21 & 51,78 \\
\hline & $\begin{array}{l}\text { Dengan mengikuti aturan wajib menggunakan e- } \\
\text { money, akan: ** }\end{array}$ & & & & & \\
\hline CC1 & Membuang waktu & 7,08 & 0,84 & 0,862 & 0 & 100 \\
\hline CC2 & Merepotkan & 7,01 & 0,87 & 0,723 & 0,29 & 99,7 \\
\hline CC3 & Menambah biava tra & 6,84 & 0,94 & 0,890 & 0.89 & 991 \\
\hline
\end{tabular}




\begin{tabular}{|l|l|r|r|r|r|r|}
\hline \multicolumn{1}{|c|}{ Pertanyaan } & Mean & StD & $\begin{array}{c}\text { Load- } \\
\text { ing }\end{array}$ & $\begin{array}{l}\text { Skor } \\
1-4\end{array}$ & $\begin{array}{l}\text { Skor } \\
5-8 *\end{array}$ \\
\hline & $\begin{array}{l}\text { Misalnya dengan tidak mengikuti aturan wajib } \\
\text { menggunakan e-money (berarti tidak dapat mengisi } \\
\text { bahan bakar), akan berakibat: }\end{array}$ & & & & & \\
\hline CNC1 & Membahayakan saya & 5,94 & 1,02 & 0,830 & 7,14 & 92,85 \\
\hline CNC2 & Berefek negatif bagi saya & 6,41 & 1,02 & 0,857 & 1,78 & 98,21 \\
\hline CNC3 & Merugikan bagi saya & 5,46 & 1,06 & 0,879 & 15,47 & 84,52 \\
\hline & $\begin{array}{l}\text { (* saat pengolahan menggunakan skala terbalik) } \\
\text { (* Total konsolidasi skor responden yang dibagi berdasarkan pendapat negatif dengan skor 1- } \\
\text { 4, dan pendapat positif skor 5-8, dalam persentase) }\end{array}$ \\
\hline
\end{tabular}

\section{HASIL DAN PEMBAHASAN}

\subsection{Uji Validitas dan Reliabilitas}

Pada SEM PLS, Validitas dinilai melalui convergent validity dan discriminant validity, sedangkan reliabilitas melalui composite reliability dan indicator reliability [23] [24] [25]. Convergent validity dinilai dari nilai factor loading yang dapat dilihat pada tabel 2. Nilai factor loading yang tinggi $(>0,7)$ menandakan pertanyaan pada kuesioner memang menanyakan sesuatu yang sama atau beberapa pertanyaan tersebut membahas satu faktor yang sama. Convergent validity juga dinilai dari nilai average variance extracted yang dapat dilihat pada tabel 3 , tolak ukurnya adalah $>0,5$.

Discriminant validity menunjukkan validitas dari membedakan satu faktor dengan faktor lainnya. Discriminant validity diwakili oleh nilai cross loading dimana nilai korelasi antar konstruk tidak boleh melebihi nilai loading konstruk (tabel fornell larcker di tabel 3). Composite reliability dan cronbach alpha dilakukan untuk mengevaluasi reliabilitas internal dari sebuah faktor dengan nilai $>0,8$ dan untuk menghindari masalah multicollinearity, nilai variance inflation factor (VIF) semuanya berada di bawah angka 5 dan dapat dilihat pada Tabel 3 dan Tabel 4. Dari hasil pengujian validitas dan reliabilitas, alat ukur memenuhi persyaratan.

Tabel 3. Hasil pengujian validitas dan reliabilitas

\begin{tabular}{|l|r|r|l|l|l|r|r|r|}
\hline & \multicolumn{1}{|c|}{$\begin{array}{c}\text { Cr Alpha } \\
\text { Reliability }\end{array}$} & $\begin{array}{c}\text { Composite } \\
\text { Reliability }\end{array}$ & \multicolumn{6}{|c|}{ Factor (VIF) } \\
\hline BC & 0.828 & 0.897 & BC1 & 1.911 & CC2 & 1.486 & EU3 & 1.794 \\
\hline BI & 0.812 & 0.889 & BC2 & 2.028 & CC3 & 1.707 & PU1 & 1.712 \\
\hline CC & 0.779 & 0.867 & BC3 & 1.771 & CNC1 & 1.655 & PU2 & 1.77 \\
\hline CNC & 0.817 & 0.891 & BI1 & 1.885 & CNC2 & 1.894 & PU3 & 1.722 \\
\hline EU & 0.816 & 0.89 & BI2 & 1.782 & CNC3 & 1.972 & TS1 & 1.773 \\
\hline PU & 0.804 & 0.883 & BI3 & 1.707 & EU1 & 1.78 & TS2 & 1.622 \\
\hline TS & 0.803 & 0.884 & CC1 & 1.715 & EU2 & 1.845 & TS3 & 1.836 \\
\hline
\end{tabular}

Tabel 4. Hasil Pengujian Validitas

\begin{tabular}{|l|c|r|r|r|r|r|r|r|}
\hline & \multirow{2}{*}{ Validity (AVE) } & \multicolumn{7}{|c|}{ Discriminant validity (Fornell Larcker) } \\
\cline { 3 - 9 } & 0.743 & \multicolumn{1}{|c|}{ BC } & \multicolumn{1}{|c|}{ BI } & CC & CNC & EU & PU & TS \\
\hline BC & 0.727 & 0.219 & $\mathbf{0 . 8 5 3}$ & & & & & \\
\hline BI & 0.686 & -0.046 & -0.106 & $\mathbf{0 . 8 2 8}$ & & & & \\
\hline CC & 0.732 & -0.022 & 0.473 & 0.005 & $\mathbf{0 . 8 5 5}$ & & & \\
\hline CNC & 0.73 & 0.001 & 0.151 & 0.069 & -0.027 & $\mathbf{0 . 8 5 4}$ & & \\
\hline EU & 0.73 & -0.051 & 0.245 & 0.078 & 0.033 & 0.026 & $\mathbf{0 . 8 4 6}$ & \\
\hline PU & 0.716 & 0.076 & 0.468 & 0.039 & 0.193 & 0.065 & 0.139 & $\mathbf{0 . 8 4 7}$ \\
\hline TS & 0.717 & 0.71 &
\end{tabular}




\subsection{Uji Path}

Sesuai dengan metode pengujian menggunakan pendekatan PLS (non parametrik), pengujian struktural model untuk melihat hubungan antar faktor dilakukan dengan bootstrapping. Pada model penelitian, bootstrapping sampling dilakukan untuk 336 sample dengan 5000 pengulangan sample [26]. Hasil estimasi model, termasuk koefisien path (hubungan antar faktor) dan jumlah varians yang dapat dijelaskan $\left(\mathrm{R}^{2}\right)$ dapat dilihat pada Gambar 3 dan Tabel 5 sampai Tabel 6.

Berdasarkan koefisien path yang signifikan, semua hipotesis alternatif diterima $(\mathrm{p}<0,05)$, kecuali untuk $\mathrm{H}_{2 \mathrm{a}}$ : EU - PU dan $\mathrm{H}_{4 \mathrm{a}}$ : TS - EU. Sebanyak 48\% varians dari faktor BI (niat menggunakan) dapat dijelaskan dari hubungan antar faktor yang dihipotesiskan pada model penelitian. Dengan kata lain, sebanyak 48\% dari niat menggunakan e-money di Pontianak dapat diprediksi dari faktor-faktor yang digunakan pada model penelitian. Kecepatan transaksi juga mempengaruhi persepsi manfaat, walaupun hanya mampu menjelaskan $0,2 \%$ dari varians pada faktor persepsi manfaat.

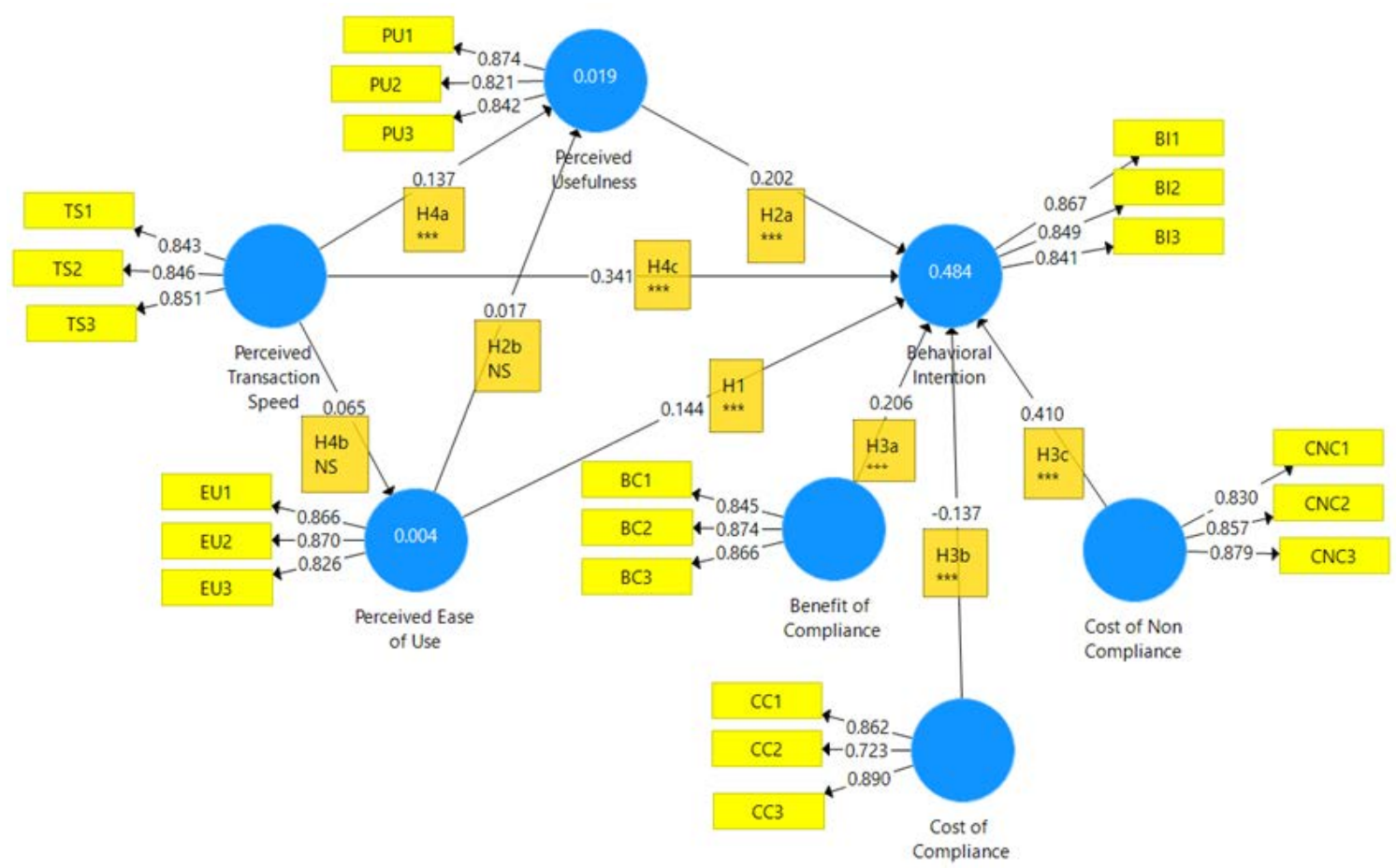

Gambar 3. Pengujian Struktural Model Konseptual Penelitian

Tabel 5. Ringkasan Hipotesis Model Penelitian

\begin{tabular}{|l|l|r|r|r|r|l|}
\hline \multicolumn{1}{|c|}{ Hyp } & \multicolumn{1}{|c|}{ Construct } & Effect & t stat & p value & & $\begin{array}{l}\text { Terima/ } \\
\text { Tolak }\end{array}$ \\
\hline $\mathrm{H}_{1}$ & $\begin{array}{l}\text { Perceived Usefulness } \rightarrow \text { Behavioral } \\
\text { Intention }\end{array}$ & 0.202 & 5.154 & 0.000 & Sig & Terima \\
\hline $\mathrm{H}_{2 \mathrm{a}}$ & $\begin{array}{l}\text { Perceived Ease of Use } \rightarrow \text { Behavioral } \\
\text { Intention }\end{array}$ & 0.147 & 3.499 & 0.001 & Sig & Terima \\
\hline $\mathrm{H}_{2 \mathrm{~b}}$ & $\begin{array}{l}\text { Perceived Ease of Use } \rightarrow \text { Perceived } \\
\text { Usefulness }\end{array}$ & 0.017 & 0.262 & 0.794 & NS & Tolak \\
\hline $\mathrm{H}_{3 \mathrm{a}}$ & $\begin{array}{l}\text { Benefit of Compliance } \rightarrow \text { Behavioral } \\
\text { Intention }\end{array}$ & 0.206 & 5.215 & 0.000 & Sig & Terima \\
\hline $\mathrm{H}_{3 \mathrm{~b}}$ & $\begin{array}{l}\text { Cost of Compliance } \rightarrow \text { Behavioral } \\
\text { Intention }\end{array}$ & -0.137 & 2.948 & 0.003 & Sig & Terima \\
\hline $\mathrm{H}_{3 \mathrm{c}}$ & $\begin{array}{l}\text { Cost of Non Compliance } \rightarrow \text { Behavioral } \\
\text { Intention }\end{array}$ & 0.41 & 10.305 & 0.000 & Sig & Terima \\
\hline
\end{tabular}




\begin{tabular}{|l|l|r|r|r|r|c|}
\hline \multicolumn{1}{|c|}{ Hyp } & \multicolumn{1}{|c|}{ Construct } & Effect & t stat & p value & & $\begin{array}{l}\text { Terima/ } \\
\text { Tolak }\end{array}$ \\
\hline $\mathrm{H}_{4 \mathrm{a}}$ & $\begin{array}{l}\text { Perceived Transaction Speed } \rightarrow \\
\text { Perceived Ease of Use }\end{array}$ & 0.065 & 1.045 & 0.296 & NS & Tolak \\
\hline $\mathrm{H}_{4 \mathrm{~b}}$ & $\begin{array}{l}\text { Perceived Transaction Speed } \rightarrow \\
\text { Perceived Usefulness }\end{array}$ & 0.139 & 2.474 & 0.014 & Sig & Terima \\
\hline $\mathrm{H}_{4 \mathrm{c}}$ & $\begin{array}{l}\text { Perceived Transaction Speed } \rightarrow \\
\text { Behavioral Intention }\end{array}$ & 0.378 & 10.992 & 0.000 & Sig & Terima \\
\hline $\begin{array}{l}\text { Indirect } \\
\text { effect }\end{array}$ & $\begin{array}{l}\text { Perceived Transaction Speed } \rightarrow \\
\text { Perceived Usefulness } \rightarrow \text { Behavioral } \\
\text { Intention }\end{array}$ & 0.028 & 2.099 & 0.036 & Sig & \\
\cline { 1 - 3 } & & & & &
\end{tabular}

Tabel 6. R², f dan q Penelitian

\begin{tabular}{|l|c|r|c|}
\hline & \multicolumn{1}{|c|}{$\mathrm{q}^{2}$} & \multicolumn{1}{c|}{$\mathrm{f}^{2}$} & \multicolumn{1}{c|}{$\mathrm{R}^{2}$} \\
\hline Perceived Usefulness & 0.038 & 0.077 & 0.014 \\
\hline Perceived Transaction Speed & 0.102 & 0.211 & \\
\hline Perceived Ease of Use & 0.019 & 0.04 & \\
\hline Benefit of Compliance & 0.039 & 0.081 & \\
\hline Cost of Compliance & 0.016 & 0.036 & \\
\hline Cost of Non Compliance & 0.153 & 0.313 & \\
\hline Behavioral Intention & & & 0.475 \\
\hline
\end{tabular}

Hasil menunjukkan penerimaan e-money calon pengguna ditentukan oleh enam faktor: perceived usefulness, perceived ease of use, perceived transaction speed, benefit of compliance, cost of compliance, dan cost of non compliance. Dari ke enam faktor tersebut (Tabel 6), cost of non compliance(CNC) merupakan faktor yang paling mempengaruhi niat untuk menggunakan emoney. CNC merupakan pertimbangan biaya / kerugian yang akan terjadi apabila melanggar aturan. Semakin tinggi kerugian karena melanggar aturan menggunakan e-money, niat menggunakan e-money juga akan semakin tinggi. Lebih dari $90 \%$ responden setuju bahwa melanggar aturan menggunakan e-money mempunyai efek negatif dan merugikan sehingga dapat disimpulkan bahwa niat menggunakan e-money responden tinggi. Walaupun mempunyai niat menggunakan e-money yang tinggi, tetapi pada prakteknya, e-money masih belum digunakan untuk aktivitas pengisian bahan bakar. Kenyataan ini dapat dijelaskan dari absennya sanksi apapun dari pemerintah terkait pelanggaran aturan wajib e-money tersebut sehingga menggunakan atau tidak menggunakan e-money tidak berakibat apapun bagi calon pengguna.

Hasil ini memberikan kontribusi penting bagi pemerintah daerah yaitu perlunya keseriusan dalam membuat peraturan, terutama dalam menyiapkan sanksi yang sesuai pada saat implementasi e-money di Pontianak. Bentuk sanksi [16] dapat berupa pengurangan keuntungan, pengurangan prestise, sampai sanksi psikologis seperti rasa malu karena tekanan sosial dari rekan, teman dan keluarga. Apabila pemerintah ingin menerapkan e-money secara menyeluruh di pengisian bahan bakar, sanksi pengurangan keuntungan berupa denda dapat menjadi pilihan untuk memaksa pengguna menggunakan e-money. Namun, dalam merumuskan sanksi, faktor etis juga menjadi pertimbangan penting karena secara tidak langsung pemerintah mengatur bagaimana masyarakat menggunakan uang sendiri, apakah etis memberikan denda kepada pengguna hanya karena cara menggunakan uang tidak sesuai dengan kehendak pemerintah.

Agar program cashless society berhasil dan tidak menimbulkan gejolak baru, sanksi perlu dirumuskan dengan ketelitian yang memadai. Bagi lembaga keuangan, hasil ini dapat ditindaklanjuti dengan aktif membantu pemerintah menciptakan sanksi psikologis dalam bentuk ajakan ataupun himbauan kepada pengguna untuk ikut menggunakan e-money karena sudah digunakan oleh teman/rekan/keluarga pengguna. Himbauan yang diberikan akan memperkuat efek tekanan sosial bagi pengguna, karena tekanan sosial mempunyai efek positif dalam adopsi sebuah sistem baru [14]. 
Faktor lain yang juga kuat mempengaruhi niat menggunakan e-money dari rational choice theory adalah benefit of compliance(BC) dan cost of compliance(CC). Pada BC, indikatorindikator dengan korelasi paling kuat adalah BC2(peraturan e-money memberikan faedah bagi saya) yang diikuti oleh BC3 (mengikuti aturan e-money menguntungkan bagi saya).

Kedua indikator menunjukkan bahwa pengguna menyadari peran dari e-money dan berniat mengikuti aturan bila aturan tersebut memberikan keuntungan. Hasil ini dapat digunakan oleh pihak pemerintah yang bekerja sama dengan lembaga keuangan misalnya dalam bentuk memberikan insentif tambahan ataupun promo karena pemakaian berulang maupun diskon khusus untuk penggunaan e-money. Walaupun selama ini strategi tersebut sudah diterapkan tetapi hasil penelitian memberikan temuan baru bahwa BC tidak lebih kuat mempengaruhi niat daripada CNC, sehingga sanksi mungkin akan lebih mempunyai efek daripada insentif.

Faktor ketiga dari RCT dan yang paling lemah mempengaruhi niat menggunakan emoney adalah Cost of Compliance (CC). Pada CC, hubungan korelasi negatif mengindikasikan semakin tinggi biaya yang dipersepsikan timbul dari mengikuti aturan wajib e-money, semakin rendah pula niat menggunakan e-money. Dari respons pengguna, hampir semuanya setuju ( $>95 \%)$ bahwa dengan menggunakan e-money akan membuang waktu (CC1), merepotkan (CC2) dan menambah biaya transaksi (CC3). Nilai korelasi indikator CC yang paling kuat mempengaruhi niat menggunakan adalah CC3 yaitu responden menganggap mengikuti aturan wajib e-money menambah biaya transaksi. Hasil tersebut dapat terkait dengan biaya mengisi ulang, dimana setiap kali mengisi ulang kartu e-money, pengguna dikenakan biaya administrasi [27]. Oleh karena itu, bagi penyedia layanan e-money, biaya administrasi isi ulang e-money seharusnya dapat diminimalkan / dihilangkan. Walaupun biaya administrasi tidak besar, tetapi secara persepsi akan menciptakan halangan dan mengurangi niat menggunakan. Nilai uang pengguna yang seharusnya penuh menjadi berkurang, pengguna perlu mengeluarkan biaya untuk menggunakan uang sendiri.

Dari hasil uji path juga dapat dilihat bahwa persepsi akan kecepatan transaksi (TS) responden mempengaruhi niat menggunakan e-money secara langsung dan tidak langsung melalui persepsi manfaat. Persepsi kecepatan transaksi (TS) mempengaruhi secara langsung niat menggunakan dan merupakan faktor kedua yang paling kuat mempengaruhi niat menggunakan e-money setelah CNC. Hasil ini mengindikasikan bahwa persepsi kecepatan transaksi calon pengguna sangatlah penting dalam memotivasi pengguna mengadopsi e-money. Dari indikator dengan korelasi paling tinggi yaitu TS3 (dibandingkan dengan tunai, e-money juga proses transaksinya cepat) dapat disimpulkan bahwa calon pengguna akan menggunakan e-money bila kecepatan proses transaksi tersebut setara atau menyamai uang tunai. Dari publikasi sekunder juga telah diketahui bahwa pengguna merasa kesulitan menggunakan e-money karena lama menunggu antrian. Antrian lama karena proses transaksi lama. Padahal teknologi e-money berbasis kartu nirkabel sangat cepat dan menyamai kecepatan tunai, dalam beberapa kasus karena tidak perlu menyediakan kembalian bahkan lebih cepat daripada tunai [9]. Kendala lain yang menyebabkan transaksi menjadi lambat, mulai dari kesiapan karyawan pemroses transaksi, sampai ketersediaan jaringan internet untuk transaksi perlu lebih diperhatikan penyedia (dalam hal ini adalah SPBU). Kesiapan karyawan dapat diperbaiki dengan memberikan pelatihan tambahan. Ketersediaan jaringan internet diperbaiki dengan melakukan tambahan atau upgrade jaringan. Semua itu memerlukan biaya, sehingga memang untuk mewujudkan cashless society, perlu kerja sama aktif dari semua pihak.

Persepsi kecepatan transaksi (TS) juga mempengaruhi niat secara tidak langsung melalui PU. Dari indikator dengan korelasi tertinggi, kecepatan yang menyamai tunai akan meningkatkan persepsi bahwa e-money lebih efisien dan akan meningkatkan niat menggunakan e-money di masa depan. Untuk meningkatkan niat menggunakan di masa depan, maka harus dimulai dari meningkatkan persepsi kecepatan transaksi dan persepsi efisiensi proses transaksi e-money. Hasil ini berguna bagi lembaga keuangan karena walaupun e-money secara teknologi lebih baik, tetapi kelebihan tersebut saat ini mungkin hanya diketahui pihak penyedia dan belum mencapai pengguna akhir. Dari respons pengguna, lebih dari 70\% pengguna tidak setuju menggunakan emoney lebih efisien (PU1) dan efektif (PU2). Pengguna juga masih cenderung tidak setuju bahwa e-money meningkatkan kecepatan transaksi (TS1) dan menghemat waktu (TS2). Hasil ini 
merupakan gambaran persepsi pengguna yang dapat diperbaiki dengan memberikan edukasi tambahan. Kecepatan transaksi e-money dalam kondisi optimal perlu diperagakan kepada pengguna, sehingga pengguna mempunyai persepsi positif terhadap kecepatan e-money. Keunggulan tersebut mencakup tidak perlunya kembalian uang receh, transaksi terproses dengan instan, tercatat dengan jelas, dengan media kartu yang kecil dapat memuat uang tunai berjumlah sangat banyak. Bagi merchant / toko, pengurangan proses pekerjaan yang ditawarkan e-money juga akan sangat membantu dan meningkatkan efisiensi pekerjaan. Peragaan ini dapat dilakukan dalam bentuk video ataupun masa percobaan sebelum penerapan benar-benar dilakukan massal. Ditambah dengan adanya training karyawan dan kesiapan pihak penyedia transaksi, sinergitas keduanya akan dapat meningkatkan minat menggunakan e-money di Pontianak.

Dari faktor perceived ease of use (EU), penelitian ini mendapatkan hasil yang sama dengan penelitian TAM sebelumnya yaitu calon pengguna akan lebih berniat menggunakan emoney apabila merasa mudah digunakan [28]. Dari indikator EU2 (e-money itu sederhana/tidak kompleks) yang juga merupakan indikator dengan korelasi tertinggi dan berhubungan positif dengan niat menggunakan menunjukkan bahwa semakin rumit penggunaan e-money maka akan semakin mengurangi niat menggunakan e-money. Hasil ini mengindikasikan bahwa pada saat transaksi, e-money harus didesain sedemikian rupa sehingga sederhana dan mudah dioperasikan. Layar pembayaran harus nampak dengan jelas, jumlah langkah yang diperlukan untuk menyelesaikan transaksi dikurangi untuk mengurangi kompleksitas penggunaan dan umpan balik yang cukup kepada pengguna akan status transaksi maupun saldo akan sangat membantu untuk mengurangi kompleksitas yang dirasakan oleh pengguna. Penyedia layanan juga dapat belajar dari studi terdahulu dimana e-money gagal diterapkan [29], yaitu unsur visualisasi saldo. Kartu e-money tidak seperti uang tunai yang nominalnya tertera secara visual sehingga mudah digunakan untuk transaksi oleh pengguna. Setiap mengeluarkan uang tunai, pengguna dapat dengan mudah menghitung nominal uang tersebut karena tertera dengan jelas. Dibandingkan dengan e-money, hanya untuk mengecek saldo saja pengguna perlu mencari alat pembaca. Kesulitan akan bertambah apabila letak alat pembaca jauh dari pengguna sehingga hanya untuk kegiatan sederhana seperti mengecek saldo, pengguna perlu mengeluarkan banyak langkah tambahan. Oleh karena itu, pihak penyedia transaksi (SPBU) harus memastikan bahwa saldo emoney pengguna dapat diketahui dengan mudah. Bagi lembaga keuangan, pengecekan saldo dapat dipermudah dengan memberikan ekstensi di mobile banking ataupun internet banking sehingga pengecekan saldo dapat dilakukan dimana saja kapan saja.

Pada perceived usefulness (PU), sama seperti penelitian sebelumnya [28] dimana TAM digunakan, perceived usefulness mempengaruhi behavioral intention secara positif. Untuk meningkatkan niat menggunakan e-money, maka terlebih dahulu harus bermanfaat bagi pengguna. Persepsi manfaat tinggi maka niat menggunakan juga tinggi. Namun, pada responden penelitian ini, e-money masih belum dirasakan manfaatnya. Dari indikator dengan korelasi paling kuat mempengaruhi niat menggunakan yaitu PU1 (e-money membuat transaksi saya lebih efisien), lebih dari $75 \%$ responden tidak setuju dengan pernyataan tersebut. Hasil ini menunjukkan bahwa untuk dapat diterima, e-money memerlukan edukasi tambahan seperti rekomendasi sebelumnya di TS. Pertimbangan lainnya yang penting diperhatikan bagi lembaga keuangan adalah ketersediaan toko yang menyediakan transaksi e-money. Belajar dari studi penerapan e-money yang gagal [29], para penjual / toko yang belum tersentuh teknologi misalnya di pasar basah, kaki lima mungkin akan kesulitan menyediakan alat pembayaran berbasis kartu seperti debit ataupun kartu kredit sampai yang berbasis contactless seperti e-money. Karena untuk menyediakan alat transaksi tersebut memerlukan biaya ataupun kelengkapan ijin usaha [31]. Sedangkan sampai akhir tahun 2017, 60\% UMKM di Indonesia tidak memiliki ijin usaha [30]. Selain itu, masih banyak pelaku usaha mungkin belum tersentuh oleh bank [31]. Dari segi kepraktisan bagi pengguna saat ini, membuat dan membawa e-money hanya untuk transaksi pengisian bahan bakar saja mungkin tidak praktis bagi pengguna sehingga dianggap tidak bermanfaat.

Dari hasil penelitian ini dapat dirangkum bahwa penerapan e-money harus dilakukan secara menyeluruh. Apabila diwajibkan, maka memerlukan sanksi, tambahan benefit, dan 
penghilangan biaya transaksi bagi pengguna. Manfaat e-money perlu diperkuat dengan ketersediaan toko yang melayani e-money, kemudahan pengecekan saldo, dan kesiapan serta kompetensi toko dalam melayani transaksi e-money.

Sebagai catatan tambahan, seperti penelitian sebelumnya [32], penerimaan teknologi di Kalimantan Barat belum optimal karena kurangnya komunikasi, apakah tidak terlalu dini untuk mewajibkan masyarakat menggunakan e-money apabila pembayaran menggunakan kartu debit / kredit saja masih belum diterima secara umum. Lebih jauh, perkembangan teknologi yang pesat mengubah pola penggunaan termasuk pembayaran menjadi berbasis mobile. Dengan penetrasi perangkat mobile yang sangat tinggi dan cepat, apakah tidak lebih baik langsung menerapkan emoney pada pembayaran berbasis mobile? hal tersebut dapat menjadi pertanyaan untuk diselidiki lebih lanjut di penelitian selanjutnya.

\section{KESIMPULAN}

Hasil ekstensi pada model TAM menggunakan Rational Choice Theory dan transaction speed memberikan pemahaman baru dalam memprediksi niat menggunakan e-money pada program wajib e-money di Pontianak. Pengguna akan berniat menggunakan e-money setelah mempertimbangkan tentang (diurutkan berdasarkan pengaruh paling kuat): kerugian tidak mengikuti aturan (CNC), kecepatan transaksi (TS), keuntungan mengikuti aturan (BC), manfaat (PU), kemudahan (EU), dan biaya mengikuti aturan (CC).

Dari ekstensi yang dilakukan, kepatuhan akan peraturan pengguna dipengaruhi paling kuat oleh pertimbangan kerugian yang timbul dari tidak mengikuti aturan. Pengguna hanya akan mematuhi aturan wajib e-money jika terdapat kerugian nyata dari tidak mematuhi aturan tersebut atau dengan kata lain, pengguna tidak mematuhi aturan karena tidak ada sanksinya. Kemudian, kecepatan transaksi e-money masih belum optimal pada saat implementasi sehingga pengguna masih menganggap bertransaksi menggunakan e-money lambat dan mengurangi niat menggunakan e-money. Kemampuan faktor-faktor yang digunakan dalam memprediksi niat menggunakan e-money adalah sebesar (R2) 48\% dengan 52\% tidak dapat dijelaskan oleh faktor yang digunakan.

\section{SARAN}

Penelitian ini terbatas pada metode sampling yang digunakan. Karena tidak tersedianya daftar nama pengguna kendaraan, maka penelitian terbatas untuk sample yang berhasil dikumpulkan sehingga perlu perhatian pada saat digeneralisasi. Sample yang diambil juga terbatas pada pengguna yang belum menggunakan sehingga pada penelitian selanjutnya dapat dikembangkan pada pengguna yang sudah menggunakan untuk dikomparasi dan pengaruhnya pada niat menggunakan.

Dari hasil penelitian ini, persepsi manfaat e-money masih rendah, terlepas dari teknologi e-money yang lebih unggul dan seharusnya memberikan lebih banyak manfaat bagi pengguna. Oleh karena itu pada penelitian selanjutnya dapat difokuskan kepada faktor manfaat (perceived usefulness) dari e-money. Faktor manfaat tersebut dapat diekstensikan dengan keunggulan relatif dari e-money untuk dapat menguji lebih lanjut persepsi pengguna akan keunggulan e-money dibanding uang tunai untuk transaksi.

Kendala pada saat transaksi juga penting untuk diteliti lebih lanjut, terutama apakah faktor kesiapan dari penjual / toko mempengaruhi penerimaan e-money. Mengambil pandangan pihak penjual / toko diharapkan dapat memberikan perspektif baru akan penerimaan e-money. Kemudian pada penelitian selanjutnya juga dapat difokuskan pada penerimaan pengguna untuk pembayaran elektronik selain menggunakan kartu misalnya melalui telepon genggam atau aplikasi smartphone. 


\section{DAFTAR PUSTAKA}

[1] Bank Indonesia, 2014, Bank Indonesia Mencanangkan Gerakan Nasional Non Tunai, https:// www.bi.go.id/id/ruang-media/siaran-pers/Pages/sp_165814.aspx, diakses pada tanggal 8 Januari 2018.

[2] Pranoto., Salsabila, S. S., 2018, Eksistensi kartu kredit dengan adanya electronic money (emoney) sebagai alat pembayaran yang sah, Jurnal Privat Law, No.1, Vol. 6, Hal. 24-33.

[3] Bank Indonesia, 2018, Peraturan Bank Indonesia Nomor 20/6/PBI/2018 tentang Uang Elektronik, https://www.bi.go.id/id/peraturan/sistem-pembayaran/Pages/PBI-200618.aspx, diakses pada tanggal 4 Januari 2018.

[4] Andilala, 2017, Pertamina sosialisasi SPBU "cashless" di Pontianak, https://www.antara news.com/berita/638820/pertamina-sosialisasi-spbu-cashless-di-pontianak, diakses pada tanggal 8 Januari 2018.

[5] Haryadi, 2017, Pontianak go cashless setengah hati, https://www.pontianakpost.co.id/ponti anak-go-cashless-setengah-hati, diakses 4 Januari 2018.

[6] Mutiasari, D., 2017, Pengguna Uang Elektronik Masih Minim, http://pontianak.tribun news.com/2017/12/19/pengguna-uang-elektronik-masih-minim, diakses pada tanggal 4 Januari 2018

[7] Syahroni, 2018, Pelayanan E-money di SPBU kota Pontianak Memperlambat Transaksi, http://pontianak.tribunnews.com/2018/01/01/pelayanan-e-money-di-spbu-kota-pontianakmemperlambat-transaksi, diakses pada tanggal 4 Januari 2018

[8] Turban, E., Brahm, J., 2000, Smart Card-Based Electronic Card Payment Systems in the Transportation Industry, Journal of Organizational Computing and Electronic Commerce, No. 4, Vol. 10, Hal. 281-293.

[9] Smart Card Alliance, 2003, Contactless payment and the retail point of sale: applications, technologies, and transaction models, New Jersey Clarksville, Smart Card Alliance.

[10] Ayudya, A. C., Wibowo, A., 2018, The Intention to Use E-Money using Theory of Planned Behavior and Locus of Control, Jurnal Keuangan dan Perbankan, No. 2, Vol. 22, Hal 335349.

[11] Nugroho, A., Najib, M., Simanjuntak, M., 2018, Factors Affecting Consumer Interest in Electronic Money Usage with Theory of Planned Behavior (TPB), Journal of Consumer Sciences, No. 01, Vol. 3, Hal. 15-27.

[12] Davis, F., 1989, Perceived usefulness, perceived ease of use, and user acceptance of information technology, MIS Quaterly, No. 3, Vol. 13, Hal 319-340.

[13] Venkatesh, V., Davis, F. D., A Theoretical Extension of the Technology Acceptance Model: Four Longitudinal Field Studies, Management Science Journal, No. 2, Vol. 46, Hal. 186204.

[14] Venkatesh, V., Morris, M. G., Davis, G. B., Davis, F. D., 2003, User Acceptance of Information Technology: Toward a Unified View, MIS Quarterly Journal, No. 3, Vol. 27, Hal. 425-478.

[15] Bulgurcu, B., Cavusoglu, H., Benbasat, I., 2010, Information Security Policy Compliance: An Empirical Study of Rationality-Based Beliefs and Information Security Awareness, MIS Quarterly, No. 3, Vol. 34, Hal. 523-548.

[16] Paternoster, R., Simpson, S., 1996, Sanction Threats and Appeals to Morality: Testing a Rational Choice Model of Corporate Crime, Law \& Society Review, No. 3, Vol. 30, Hal 549583. 
[17] Chen, L. D., 2008, A model of consumer acceptance of mobile payment, International Journal of Mobile Communications, No. 1, Vol. 6, Hal. 32-52.

[18] Teo, A. C., Tan, G. W. H., Ooi, K. B., Hew, T. S., Yew, K. T., 2015, The Effects of convenience and speed in m-payment, Industrial Management \& Data Systems, No. 2, Vol. 115, Hal. 311-331

[19] Sekaran U., Bougie, R., 2017, Research Methods for Business: A Skill Building Approach, Wiley, New Jersey, US.

[20] Biro Pusat Statistik, 2017, Provinsi Kalimantan Barat Dalam Angka, BPS Provinsi Kalimantan Barat.

[21] Fishbein, M., Ajzen, I., 1975, Belief, Attitude, Intention and Behavior: An introduction to Theory and Research, Addison-Wesley Reading, Boston.

[22] Ajzen, I., 1985, From intentions to actions: a theory of planned behavior, Action Control: From Cognition to Behavior, Springer, Verlag Berlin Heidelberg

[23] Sarstedt, M., Ringle, C., Hair, J. F., 2017, Partial Least Squares Structural Equation Modeling, Handbook of Market Research, Springer, Verlag Berlin Heidelberg.

[24] Hair, J. F., et al, 2014, A Primer on Partial Least Square Structural Equation Modeling, Sage, London.

[25] Hair, J. F., 2017, Advanced issues in partial least squares structural equation modeling, Sage, London.

[26] Davison, A. C., Hinkley, D. V., 2013, Bootstrap Methods and Their Application, Cambridge University Press, London.

[27] Bank Indonesia, 2017, Peraturan Anggota Dewan Gubernur No.19/10/PADG/2017 tentang Gerbang Pembayaran Nasional (National Payment Gateway), https://www.bi.go.id/id/ peraturan/sistem-pembayaran/Pages/PADG_191017.aspx, diakses pada tanggal 21 Desember 2018.

[28] Marangunic, N., Granic, A., 2015, Technology acceptance model: a literature review from 1986 to 2013, Universal Access in the Information Society, Vol 14, hal 81-95.

[29] Plouffe, C. R., Vandenbosch, M., Hulland, J., 2000, Why smart cards have failed: looking to consumer and merchant reactions to a new payment technology, International Journal of Bank Marketing, No. 3, Vol. 18, Hal. 112 - 123.

[30] Susanti, R., 2017, 60 persen umkm di indonesia belum memiliki ijin, https://ekonomi. kompas.com/read/2017/11/19/102521626/60-persen-umkm-di-indonesia-belum-memilikiizin, diakses pada tanggal 21 Desember 2018.

[31] Saputra, P., 2018, Alasan Orang Indonesia tak punya rekening bank, https://katadata.co.id /grafik/2018/05/29/alasan-orang-indonesia-tak-punya-rekening-bank, diakses pada tanggal 21 Desember 2018.

[32] Wingdes, I., 2015, Penerimaan Teknologi Web Cek-in pada pengguna transportasi udara di Kalimantan Barat, Creative Information Technology Journal, No. 1, Vol. 3, hal 37-49. 